DOI 10.14746/ssp.2020.2.5

Łukasz JUREŃCZYK

Uniwersytet Kazimierza Wielkiego w Bydgoszczy

ORCID: 0000-0003-1149-925X

\title{
Działania Wielkiej Brytanii na rzecz wzmocnienia bezpieczeństwa północno-wschodniej flanki NATO w obliczu aktywności wojskowej Rosji na Ukrainie
}

Streszczenie: Przedmiotem artykułu są działania Wielkiej Brytanii ukierunkowane na zwiększenie bezpieczeństwa państw północno-wschodniej flanki NATO w kontekście kryzysu na Ukrainie. W pierwszej części tekstu omówione zostało zaangażowanie Wielkiej Brytanii w zapewnienie bezpieczeństwa Polski i państw bałtyckich w XX wieku, w tym przede wszystkim zachowanie przez nie niepodległości. Druga część poświęcona została reakcji Londynu na działania zbrojne Rosji na Ukrainie w obszarze politycznym i gospodarczym. W trzeciej części omówiono wojskowe aspekty wsparcia przez Wielką Brytanię bezpieczeństwa Polski i państw Bałtyckich w okresie kryzysu na Ukrainie. Zakres politycznej reakcji Londynu na kryzys na Ukrainie był ograniczony. Nie mniej jednak Wielka Brytania zdecydowanie włączyła się w działania wojskowe na rzecz wzmocnienia bezpieczeństwa państw północno-wschodniej flanki NATO.

Słowa kluczowe: Wielka Brytania, kryzys na Ukrainie, północno-wschodnia flanka NATO, stosunki brytyjsko-rosyjskie

\section{Wstęp}

Tryzys na Ukrainie ma bardzo poważne konsekwencje dla Europy, \zarówno w wymiarze politycznym, jak i militarnym. Doprowadził on do znacznego ograniczenia współpracy między państwami Zachodu i Rosją. Spowodował także, że państwa NATO, w tym przede wszystkim te leżące na jego wschodniej flance, ponownie zaczęły odczuwać zagrożenie militarne ze strony wschodniego sąsiada. Działania podejmowane przez społeczność międzynarodową jak dotąd nie doprowadziły do zakończenia kryzysu. Destabilizacja Ukrainy, a w pewnym stopniu także całego regionu Europy Środkowo-Wschodniej, nadal ma miejsce. W związku z tym strony podejmują zabiegi ukierunkowane na przygotowanie się nawet na najbardziej katastroficzne scenariusze. 
Celem artykułu jest analiza i ocena posunięć Wielkiej Brytanii na rzecz wzmocnienia bezpieczeństwa północno-wschodniej flanki NATO w obliczu aktywności wojskowej Rosji na Ukrainie. Główny problem badawczy zawiera się w pytaniu, czy Wielka Brytania w istotnym stopniu zaangażowała się działania ukierunkowane na zwiększenie poziomu bezpieczeństwa Polski i państw bałtyckich w obliczu kryzysu na Ukrainie? W celu zrozumienia podejścia Wielkiej Brytanii ważne jest ukazanie politycznej reakcji Londynu na kryzys na Ukrainie. Główną tezą artykułu jest stwierdzenie, że Wielka Brytania z dużą determinacją włączyła się w działania na rzecz wzmocnienia bezpieczeństwa państw północno-wschodniej flanki NATO w obliczu wzrastającego zagrożenia ze strony Rosji. Mniejsze było z kolei jej zaangażowanie w rozwiązanie samego kryzysu na Ukrainie. Podczas pisania artykułu zastosowano metodę analizy źródeł tekstowych oraz metodę genetyczną.

\section{Reakcja Wielkiej Brytanii na działania zbrojne Rosji na Ukrainie}

Londyn, podobnie jak stolice szeregu innych państw, zaskoczony był tempem i intensywnością działań podejmowanych przez Rosję na terytorium Ukrainy, w tym przede wszystkim zajęciem i aneksją Krymu dokonanymi na przełomie lutego i marca 2014 r. Wielka Brytania miała szczególne zobowiązania w zakresie zapewnienia bezpieczeństwa Ukrainie. Wynikało to nie tylko z faktu stałego członkostwa w Radzie Bezpieczeństwa ONZ, ale przede wszystkim bycia sygnatariuszem $\mathrm{Me}$ morandum budapesztańskiego z 1994 r., gwarantującego suwerenność i niepodzielność terytorialną Ukrainy w zamian za zrzeczenie się przez nią broni jądrowej (Memorandum, 1994). W latach poprzedzających kryzys Londyn próbował ocieplić stosunki z Rosją, w związku z czym po jego rozpoczęciu początkowo wahał się jaką przyjąć strategię działania. Po tym jak kryzys się rozwinął rząd Davida Camerona przyjął stanowczą postawę, jednoznacznie potępiając działania Rosji (Tomaszewski, 2015, s. 26). 3 marca 2014 r. minister spraw zagranicznych William Hague określił pogarszającą się sytuację na Ukrainie mianem „największego kryzysu w Europie w XXI wieku". Przestrzegł świat, że musi go zahamować oraz ostrzegł Rosję, że Wielka Brytania i inne państwa podchodzą do niego bardzo poważnie. Tego samego dnia premier Cameron zasygnalizował, że jeśli Rosja nie wycofa żołnierzy z Ukrainy to będzie musiała się liczyć 
z ,dyplomatycznymi, politycznymi i ekonomicznymi sankcjami oraz innymi formami presji”" (Morris, Usborne, 2014).

Wielka Brytania znalazła się w grupie państw Unii Europejskiej najbardziej zdecydowanie opowiadających się za nałożeniem, a później rozszerzeniem sankcji gospodarczych na Rosję. Stało się tak mimo, że mogły one negatywnie przełożyć się na handel brytyjsko-rosyjski, jak i rosyjskie inwestycje w londyńskim City. Brytyjski rząd miał jednak nadzieję, że sankcje gospodarcze szybko wymuszą na Moskwie zmianę polityki, dlatego aktywnie lobbował ich wprowadzenie na forum Unii Europejskiej i państw G-7. Z kolei w Organizacji Narodów Zjednoczonych Wielka Brytania działała na rzecz uchwalenia rezolucji Zgromadzenia Ogólnego nr 68/262 z 27 marca 2014 r. dotyczącej integralności terytorialnej Ukrainy (General Assembly UN, 2014). Londyn był również aktywny po zestrzeleniu 17 lipca 2014 r. samolotu pasażerskiego Malaysia Airlines lotu MH17 w obwodzie donieckim kierowanym pociskiem rakietowym ziemia-powietrze Buk M1 należącym do Sił Zbrojnych Federacji Rosyjskiej. Na pokładzie samolotu zginęło między innymi dziesięcioro obywateli Wielkiej Brytanii. Brytyjski rząd zdecydowanie potępił zamach i wezwał Moskwę do zaprzestania zbrojenia działających na terytorium Ukrainy separatystów (House of Lords, 2015, s. 29).

Wielka Brytania sceptycznie podeszła natomiast do działań dyplomatycznych Organizacji Bezpieczeństwa i Współpracy w Europie, których konsekwencją było podpisanie Protokołu mińskiego z 5 września 2014 r. (Protocol, 2014). W praktyce podjęte przez strony zobowiązanie do zawieszenia broni nie zostało zrealizowane. W związku z tym niemiecka kanclerz Angela Merkel i francuski prezydent François Hollande podjęli się misji dyplomatycznej na rzecz stabilizacji sytuacji na Ukrainie. W lutym 2015 r. pojechali oni do Mińska, żeby negocjować zawieszenie broni między Ukrainą a Rosją i separatystami z samozwańczych republik donieckiej i ługańskiej. Premier Cameron odmówił uczestnictwa w podróży, kontaktując się jedynie telefonicznie z jej uczestnikami. Jeden z brytyjskich dyplomatów określi tę misję jako „dyplomację na próżno” („vanity diplomacy”) (Gowland, 2017, s. 314). Efektem działań Berlina i Paryża było podpisanie 11 lutego 2015 r. Pakietu Działań na rzecz Implementacji Porozumień Mińskich (Package, 2015). Ustalono w nim między innymi zawieszenie broni, wycofanie z terytorium Ukrainy obcych wojsk i rozbrojenie nielegalnych grup. Rząd brytyjski poparł porozumienie i przyjął stanowisko, że należy utrzymać sankcje wobec Rosji aż do momentu wywiązania się przez nią z porozumień z Mińska (Tomaszewski, 2015, s. 26). 
W reakcji na kryzys Wielka Brytania wprowadziła szereg ograniczeń w stosunkach bilateralnych z Rosją. Zawiesiła regularne spotkania ministrów obrony i ministrów spraw zagranicznych. Podobnie stało się z pracami międzyrządowej komisji nadzorującej współpracę handlową. Ponadto odwołano między innymi wizytę burmistrza Londynu w Moskwie i podróż delegacji brytyjskiej na paraolimpiadę w Soczi. Zaprzestano również przygotowań na posiedzenie państw G-8, którego w Soczi Rosja miała być gospodarzem. Z kolei kontakty premiera i ministra spraw zagranicznych z odpowiednikami w Moskwie ograniczone zostały do spraw dotyczących bezpieczeństwa Ukrainy (House of Lords, 2015, s. 29).

W Strategii Bezpieczeństwa Narodowego (SBN) Wielkiej Brytanii z listopada 2015 r. stwierdzono, że „Rosja stała się bardziej agresywna, autorytarna i nacjonalistyczna, coraz bardziej definiując się w opozycji wobec Zachodu. Nielegalna aneksja Krymu w 2014 r. i utrzymujące się wsparcie dla separatystów na wschodniej Ukrainie poprzez użycie spornych taktyk hybrydowych i manipulację mediami pokazało chęć Rosji do podważenia szerszych standardów międzynarodowej współpracy na rzecz zabezpieczenia własnych interesów" (Her Majesty Government, 2015, s. 18). W dokumencie Wielka Brytania zadeklarowała wsparcie dla rozwiązania kryzysu na Ukrainie metodami dyplomatycznymi i złożyła przyrzeczenie prowadzenia działań ukierunkowanych na utrzymanie suwerenności Ukrainy i wsparcia jej mieszkańców w budowaniu oporu przeciwko Rosji. Zapowiedziała kontynuację udzielania pomocy humanitarnej, doradztwa i wsparcia w zwalczaniu korupcji oraz pomocy w reformowaniu sektora obronnego i szkoleniu Sił Zbrojnych Ukrainy (Her Majesty Government, 2015, s. 54).

Jak wspomniano, główną formą nacisku Wielkiej Brytanii na Rosję, w celu zmiany przez nią polityki wobec Ukrainy, była presja sankcyjna. Sankcje nakładane były w ścisłej współpracy z partnerami z Unii Europejskiej i Stanami Zjednoczonymi. Początkowo nałożono je na oligarchów blisko współpracujących z reżimem Władimira Putina i wysokich urzędników państwowych. Następnie rozszerzano ograniczenia na poszczególne sektory rosyjskiej gospodarki (David, 2016, s. 49). Równolegle praktycznie od początku kryzysu Wielka Brytania wspierała Ukrainę pod względem humanitarnym. Włączyła się także we wsparcie rozwoju sektora obronnego tego państwa. Na szczycie NATO w Newport z 4-5 września 2014 r. zadeklarowała objęcie kierownictwa nad jednym z funduszy powierniczych dla Ukrainy - tzw. NATO C4 (Command, Control, Communications and Computers), na który przeznaczyła 
400 tys. euro. Jednocześnie zaczęła przekazywać Siłom Zbrojnym Ukrainy nieletalny sprzęt wojskowy, przeznaczając na ten cel tylko do końca 2014 r. 840 tys. funtów. W marcu 2015 r. Wielka Brytania wysłała na Ukrainę instruktorów w celu szkolenia jej sił zbrojnych. Plan szkolenia zakładał jednorazową obecność na Ukrainie 75 żołnierzy brytyjskich, podzielonych na cztery zespoły instruktorskie. Ich zadaniem było przeszkolenie do końca 2015 r. 2 tys. członków personelu wojskowego. Wsparła również Misję Doradczą Unii Europejskiej na Ukrainie (European Union Advisory Mission to Ukraine - EUAM) rozpoczętą 1 grudnia 2014 r. Jej celem jest wsparcie reformy cywilnego sektora bezpieczeństwa, na rzecz wzrostu jego efektywności, odpowiedzialności i poziomu zaufania społecznego. Dotyczy to głównie szkolenia personelu Ministerstwa Spraw Wewnętrznych, Policji Państwowej, Służby Bezpieczeństwa Ukrainy, Państwowej Służby Straży Granicznej, Biura Prokuratora Generalnego, sądów i podmiotów zwalczających korupcję (About). Jednocześnie Londyn zapowiedział wielopłaszczyznowe działania na rzecz wzmocnienia bezpieczeństwa państw wschodniej flanki NATO, w tym Polski i państw bałtyckich (Tomaszewski, 2015, s. 28).

Kolejny rząd brytyjski podtrzymał główne kierunki działań politycznych w kwestii kryzysu na Ukrainie. W listopadzie 2017 r. premier Theresa May zarzuciła Rosji nie tylko destabilizację Ukrainy, ale również grożenie światowemu porządkowi, podkopywanie autorytetu zachodnich instytucji, naruszanie przestrzeni powietrznej i wkraczanie na wody terytorialne wielu państw europejskich, ingerowanie w wybory w innych państwach oraz prowadzenie kampanii misinformacji i szpiegostwa internetowego. Szef Sztabu Generalnego Nick Carter określił z kolei Rosję największym zagrożeniem państwowym dla Wielkiej Brytanii od zakończenia zimnej wojny, ostrzegając, że Siły Zbrojny Jej Królewskiej Mości w razie konieczności dorównają wojskom rosyjskim na polu walki (Koval, 2018, s. 96-97). Rząd Wielkiej Brytanii poinformował, że tylko w 2017 r. rosyjskie okręty wojenne ponad trzydzieści razy prowadziły działania w pobliżu jej wód terytorialnych (Lorenz, 2019). W pierwszej połowie 2018 r. stosunki brytyjsko-rosyjskie uległy dalszemu pogorszeniu. Spowodowane było to otruciem 4 marca w Salisbury rosyjskiego oficera wywiadu wojskowego współpracującego z brytyjskimi służbami wywiadowczymi - Siergieja Skripala i jego córki. W odpowiedzi 15 marca premier May zdecydowała o wydaleniu z Wielkiej Brytanii 23 rosyjskich dyplomatów. To z kolei spowodowało wydalenie z Rosji 23 brytyjskich dyplomatów i zawieszenie kontaktów na wysokim szczeblu politycznym (Kramer, 2018). 


\section{Działania Wielkiej Brytanii w płaszczyźnie wojskowej na rzecz zabezpieczenia państw północno-wschodniej flanki NATO}

Podczas szczytu NATO w Newport Polska i państwa bałtyckie zdecydowanie zabiegały o zabezpieczenie wschodniej flanki Sojuszu przed wzrastającym zagrożeniem ze strony Rosji. Postulaty tych państw uzyskały jednoznaczne wsparcie ze strony delegacji brytyjskiej. Na szczycie przyjęto „Plan Działania na rzecz Gotowości” („Readiness Action Plan"), w ramach którego zdecydowano między innymi o powołaniu sił natychmiastowego reagowania, ciągłej obecności wojsk NATO w Polsce i państwach bałtyckich, zwiększeniu intensywności ćwiczeń sojuszniczych $\mathrm{w}$ regionie i aktualizacji planów ewentualnościowych (Wales, 2014). W SBN z 2015 r. Wielka Brytania potwierdziła swoją gotowość do realizacji postanowień szczytu na rzecz wzmocnienia wschodniej flanki Sojuszu. Zapewniła, że pozostanie najpotężniejszą siłą militarną w Europie, aby być w stanie wspierać sojuszników w obliczu zagrożenia ze strony Rosji. W dokumencie zapowiedziano objęcie przez Londyn przewodniej roli w tworzeniu Połączonych Wielonarodowych Sił Zadaniowych o Bardzo Wysokim Stopniu Gotowości (Very High Readiness Joint Task Force - VJTF). Zapewniono o angażowaniu się Królewskich Sił Powietrznych (Royal Air Force) w misję NATO „Baltic Air Policing” oraz udziale Wojsk Lądowych (British Army), Royal Navy, Royal Air Force i Sił Specjalnych (Special Forces) w wielonarodowych ćwiczeniach i manewrach realizowanych w celu zapewnienia bezpieczeństwa sojusznikom z wschodniej flanki Sojuszu. Ogłoszono również włączenie się Wielkiej Brytanii w Transatlantycką Inicjatywę Szkolenia i Doskonalenia Zdolności (Trans-Atlantic Capability Enhancement and Training Initiative - TACET) w państwach bałtyckich i Polsce, realizowaną poprzez wymianę doświadczeń i wiedzy wojskowej (Her Majesty Government, 2015, s. 51). W 2015 r. Wielka Brytania przystąpiła także do struktury zlokalizowanego w Szczecinie Wielonarodowego Korpusu Północny-Wschód (Multinational Corps Northeast - MNC NE).

Londyn zrealizował podjęte wobec Polski i państw bałtyckich zobowiązania i obietnice ze szczytu w Newport i SBN. Wielka Brytania została jednym z siedmiu państw ramowych przewodzących VJTF. Zadaniem tzw. szpicy jest błyskawiczne reagowanie, niektórych jej elementów nawet w przeciągu 2-3 dni, na pojawiające się kryzysy, aby zapobiec ich eskalacji. Zgodnie z założeniem w jej skład miała wejść wielonarodowa brygada w liczebności 5 tys. żołnierzy, złożona z pięciu batalionów lądo- 
wych, wspieranych przez jednostki powietrzne, morskie i specjalne (Allied Command Operations, 2015). Brytyjczycy każdorazowo delegują do VJTF grupę bojową w liczbie przynajmniej ok. 1 tys. żołnierzy. W styczniu 2017 r. w koszarach Imjin w hrabstwie Gloucester Wielka Brytania przejęła dowództwo nad VJTF. W związku z tym kontrybuowała do nich aż 3 tys. żołnierzy, głównie z 20. Brygady Pancernej (20th Armoured Brigade), ale także batalion piechoty i grenadierów oraz jednostkę artylerii, inżynieryjną i logistyczną. W skład szpicy dowodzonej przez Brytyjczyków weszły także pododdziały ze Stanów Zjednoczonych, Danii, Hiszpanii, Norwegii i Polski (Ministry of Defence, 2017).

Wielka Brytania wsparła również tworzenie Jednostek Integracji Sił NATO (NATO Forces Integration Unit - NFIU) na wschodniej flance Sojuszu, w tym w Polsce i państwach bałtyckich. Jednostki te mają zapewnić jak najszybsze rozmieszczenie VJTF i innych sił sojuszniczych w celu realizacji zadań w regionie. Po sformowaniu NFIU we wrześniu $2015 \mathrm{r}$. Londyn skierował po jednym żołnierzu do każdego z nich (Tomaszewski, 2015 , s. 28). Wielka Brytania zaangażowała się także w opracowanie tzw. planów ewentualnościowych na wypadek wystąpienia w Europie Środkowo-Wschodniej różnych scenariuszy, w tym agresji zbrojnej ze strony Rosji. Znacząco zwiększyła również liczbę żołnierzy delegowanych na ćwiczenia i manewry wojskowe z $700 \mathrm{w} 2011$ r. do 4 tys. w 2015 r. i ponad 9 tys. w 2016 r. Należy podkreślić, że głównie realizowane były one na terenie Polski i państw bałtyckich oraz na Morzu Bałtyckim. W 2016 r. Royal Navy skierowała na Morze Bałtyckie do Standing NATO Maritime Group fregatę i niszczyciela, w celu patrolowania akwenu. Londyn wysłał także do Polski samolot Boeing E-3 Sentry z zadaniem patrolowania jej przestrzeni powietrznej. Wielka Brytania uzyskała również status, obok USA i Niemiec, państwa przewodzącego inicjatywie TACET zainaugurowanej w lutym 2016 r. (Koval, 2018, s. 99-100).

Podczas szczytu NATO w Warszawie z 8-9 lipca 2016 r. podjęto decyzję o realizacji koncepcji wzmocnionej Wysuniętej Obecności (enhanced Forward Presence - eFP). W trakcie obrad ustalono skierowanie do Polski i państw bałtyckich wielonarodowych batalionowych grup bojowych. Ich formowanie miało być koordynowane przez tzw. państwa ramowe, obejmujące dowództwo oraz kontrybuujące najwięcej żołnierzy i sprzętu do grupy (Warsaw, 2016). Delegacja brytyjska zdecydowała o objęciu, jako państwo ramowe, grupy kierowanej do Estonii. Brytyjscy żołnierze już wcześniej stacjonowali w tym państwie w ramach misji NATO „Baltic Air Policing”, prowadzonej w celu strzeżenia przestrzeni powietrznej państw bałtyckich. 
Cztery brytyjskie samoloty Eurofighter Typhoon stacjonowały w okresie czteromiesięcznych zmian w latach 2015 i 2016, a później także w 2019 r. w estońskiej bazie powietrznej Ämari $(R A F, 2019)$. Warto nadmienić, że wojska brytyjskie i estońskie miały wcześniej możliwość współpracy operacyjnej także podczas misji ekspedycyjnych NATO. Przede wszystkim kontyngent z Estonii wspierał Brytyjczyków w prowincji Helmand, uznawanej za jedną z najbardziej niebezpiecznych w Afganistanie (Cawkwell, 2016, s. 60). Poza Estonią Wielka Brytania postanowiła również delegować swoich żołnierzy do batalionowej grupy bojowej stacjonującej w Polsce.

Rozmieszczenie sił brytyjskich w Estonii w ramach eFP zrealizowano na przełomie marca i kwietnia 2017 r. w ramach operacji pod kryptonimem CABRIT (Enhanced). Podczas uroczystości przywitania wojsk brytyjskich na lotnisku bazy Ämari, zlokalizowanej 25 mil na południowy zachód od Tallina, minister obrony Wielkiej Brytanii sir Michael Fallon powiedział, że „w obliczu wzrastającej stanowczości Rosji NATO staje na wysokości zadania w realizacji zobowiązań w zakresie kolektywnej obrony [...] Brytyjskie siły będą odgrywały wiodącą rolę w Estonii i wspierały sojuszników z USA w Polsce, jako część szerszych wysiłków obronnych NATO. Nasz wzrastający budżet obronny oznacza, że możemy utrzymywać to rozmieszczenie w długim okresie czasu i wzmocnić nasze oddanie bezpieczeństwu europejskiemu" (tłumaczenie za: Press Association, 2017). Pierwszą zmianę brytyjskiego kontyngentu stanowił 5 Batalion Strzelców (5th Battalion The Rifles), który w październiku zastąpiony został przez 1 Batalion Królewskiej Walii (1st Battalion The Royal Welsh), a w kolejnych zmianach przez inne bataliony (The Royal, 2017). Wspierane były one przez pododdziały logistyczne, inżynieryjne, wywiadowcze i rozpoznania. Brytyjscy żołnierze wyposażeni zostali w ok. 300 pojazdów, w tym uznawane za jedne z najlepszych na świecie czołgi Challenger 2, bojowe wozy piechoty Warrior i samobieżne armatohaubice AS-90 (Telegraph Reporters, 2017). W międzynarodowej grupie bojowej w Estonii poza Brytyjczykami w poszczególnych zmianach służyło również po kilkuset żołnierzy z Belgii i Francji. W kwaterze głównej pracowało także po kilku oficerów z Danii i cywil z Islandii, która nie posiada sił zbrojnych (NATO's, 2019, s. 2).

Jak wspomniano, żołnierze brytyjscy weszli również w skład batalionowej grupy bojowej stacjonującej od kwietnia 2017 r. w Polsce w Orzyszu. Państwem ramowym tej grupy, a jednocześnie kontrybutorem między 800 a 900 żołnierzy, w tym Szwadronu kawalerii pancernej (Armoured cavalry squadron), są Stany Zjednoczone (NATO’s, 2019, 
s. 2). Brytyjczycy delegowali do grupy między 140 a 150 żołnierzy Lekkiego szwadronu rozpoznania (Light reconnaissance squadron) z pułku Light Dragoons. Poszczególne szwadrony pułku stacjonują w Orzyszu na zasadzie stałej rotacji, zmieniając się co pół roku. Ich głównym zadaniem jest zapewnienie rozpoznania, tj. zbieranie informacji z przedpola i przekazywanie ich do sztabu. W razie potrzeby mogą one być również wykorzystywane jako lekka piechota, w tym mogą skutecznie zwalczać pojazdy wroga, także czołgi (Korsak, Miernicka, 2017). Podstawowym wyposażeniem szwadronu jest w prawie 50 lekkich pojazdów rozpoznawczych Jackal. Charakteryzują się one dużą zwrotnością i mobilnością, również w bardzo trudnym terenie. Szwadron dysponuje także bezzałogowymi statkami powietrznymi (Zieliński, 2017). Brytyjscy żołnierze biorą, wspólnie z Polakami i innymi narodowościami, udział w ćwiczeniach na terenie Polski, w tym z cyklu „Puma”, „Saber Strike” czy „Dragon”. W skład batalionowej grupy bojowej stacjonującej w Polsce obok Amerykanów i Brytyjczyków wchodzą również żołnierze z Rumunii i Chorwacji.

Wszystkie batalionowe grupy bojowe NATO stacjonujące w państwach wschodniej flanki podporządkowane zostały koordynacji nowo sformowanego Dowództwa Wielonarodowej Dywizji Północny-Wschód (Multinational Division Northeast - MND NE) w Elblągu. W poszczególnych państwach rozmieszczenia podlegają one z kolei lokalnym brygadom wojsk lądowych. W Estonii Brytyjczycy działają w ramach 1 Brygady Piechoty (1. Jalaväebrigaad) (Hankewitz, 2019), a w Polsce 15 Giżyckiej Brygady Zmechanizowanej (Lesiecki, 2018).

Podczas szczytu NATO w Brukseli z 11-12 lipca 2018 r. Wielka Brytania optowała za utrzymaniem postanowień szczytów z Newport i Warszawy dotyczących wzmocnienia wschodniej flanki Sojuszu. Poparciem Londynu cieszyła się również decyzja dotycząca utrzymania w mocy zawieszenia wojskowej i cywilnej współpracy z Rosją, przy otwartości na dialog polityczny (Brussels, 2018). Londyn poparł także kontynuowanie wsparcia reform sektora bezpieczeństwa Ukrainy i zapowiedział skierowanie do tego państwa większej liczby instruktorów wojskowych (Nicholls, 2018).

\section{Zakończenie}

Jako sygnatariusz Memorandum budapesztańskiego Wielka Brytania ponosi szczególną odpowiedzialność za suwerenność i integralność teryto- 
rialną Ukrainy. Gdy wybuchł kryzys na Ukrainie brytyjski rząd nie wziął na siebie jednak przewodniej roli politycznej w działaniach na rzecz jego rozwiązania. Zdecydowanie potępiał politykę Moskwy, w tym na forum Organizacji Narodów Zjednoczonych i aktywnie lobbował nałożenie na Rosję sankcji gospodarczych. Nie włączył się jednak bezpośrednio w działania dyplomatyczne ukierunkowane na zakończenie kryzysu na Ukrainie. W związku z tym aktywność Londynu mogła być znacznie większa, bardziej zdecydowana i widoczna (House of Lords, 2015, s. 29). W praktyce stała ona w tle presji kierowanej wobec Moskwy z Waszyngtonu i działań dyplomatycznych prowadzonych przez Berlin i Paryż. Ponadto Wielka Brytania nie opracowała strategicznej odpowiedzi na działania Rosji w długim terminie.

Znacznie bardziej zdecydowane działania Wielka Brytania podjęła w obszarze wojskowym na rzecz zapewnienia bezpieczeństwa sojusznikom z północno-wschodniej flanki NATO. Wynikało to z faktu, że Londyn uznał aktywność militarną Rosji na Ukrainie za strategiczne zagrożenie dla bezpieczeństwa Europy, w tym także Wielkiej Brytanii. Szczególnie wrażliwy był na potrzeby bezpieczeństwa sąsiadujących z Rosją Polski i państw bałtyckich. Londyn stał się jednym z czołowych graczy formułujących odpowiedź NATO na destabilizacyjne działania Moskwy. Zdecydowanie wsparł postulaty zgłaszane przez Polskę i państwa bałtyckie na szczytach NATO w Newport i Warszawie (Koval, 2018, s. 99). Wywiązał się z podjętych zobowiązań, podejmując szereg działań na rzecz faktycznego wzmocnienia bezpieczeństwa państw północno-wschodniej flanki NATO. Działania te pokazały, że w XXI wieku Wielka Brytania nadal odgrywa ważną rolę w zakresie utrzymania bezpieczeństwa w Europie, jak również jest wiarygodnym sojusznikiem aktywnie działającym w NATO. Mimo promowania koncepcji „Global Britain” obrona zbiorowa w ramach NATO i obecność wojskowa na północno-wschodniej flance Sojuszu mają pozostać kluczowymi elementami polityki bezpieczeństwa Wielkiej Brytanii także po brexicie (Szymański, 2019).

Warto zaznaczyć, że Wielka Brytania ani inne państwa NATO nie były gotowe na podjęcie bardziej zdecydowanych działań militarnych na terytorium Ukrainy, ograniczając się do pomocy w reformie jej sektora bezpieczeństwa i szkoleniu armii oraz dostarczając nieletalny sprzęt wojskowy. Nie było to jednak zaskoczeniem, ponieważ o przeprowadzeniu interwencji humanitarnej najczęściej nie decydują uzasadnienia prawne, a czynniki polityczne (Rowe, 2016, s. 36). Opinia publiczna zasadniczo wrażliwa jest na argumenty takie jak popełnianie zbrodni wojennych, czy konieczność ochrony kobiet i dzieci. Z drugiej jednak strony wcześniejsze 
doświadczenia uczestnictwa Wielkiej Brytanii w misjach wojskowych, w tym w Iraku, Afganistanie i Libii, powodowały, że politycy podchodzili do tej kwestii bardziej wstrzemięźliwie. Było to dostrzegalne nie tylko wobec Ukrainy, ale również Syrii, w której skala łamania podstawowych praw człowieka jest nieporównywalnie większa.

\section{Bibliografia}

About Us, EUAM Ukraine. http://www.euam-ukraine.eu/our-mission/about-us/, 16.04.2019.

Allied Command Operations (2015), NATO Response Force / Very High Readiness Joint Task Force. Fact Sheet, 9.03.2015, Internet Archive, https://web.archive.org/web/20150414014221/http://www.aco.nato.int/page349011837.aspx, 16.04.2019.

Brussels Summit Declaration Issued by the Heads of State and Government participating in the meeting of the North Atlantic Council in Brussels 11-12 July 2018, Brussels, 12.07.2018, NATO, https://www.nato.int/cps/en/natohq/official_texts_156624.htm.

Cawkwell T. W. (2016), UK Communication Strategies for Afghanistan, 2001-2014, Routledge, London-New York.

David S. (2016), Obama: the reluctant realist, w: US Foreign Policy and Global Standing in the $21^{\text {st }}$ Century. Realities and Perceptions, red. E. Inbar, J. Rynhold, Routledge, London-New York.

Enhanced Forward Presence (eFP), UK Army, https://www.army.mod.uk/deployments/baltics/, 16.04.2019.

General Assembly UN, Resolution adopted by the General Assembly on 27 March 2014. 68/262. Territorial integrity of Ukraine, New York, 27.03.2014, United Nations, https://www.un.org/en/ga/search/view_doc.asp?symbol=A/ RES/68/262, 10.04.2019.

Gowland D. (2017), Britain and the European Union, Routledge, London-New York.

Hankewitz S. (2019), Estonia awards 600 British troops for their service, 25.02.2019, „Estonian World”, https://estonianworld.com/security/estonia-awards-600-british-troops-for-their-service/.

Her Majesty Government (2015), National Security Strategy and Strategic Defence and Security Review 2015. A Secure and Prosperous United Kingdom, London, Assets, https://assets.publishing.service.gov.uk/government/uploads/ system/uploads/attachment_data/file/478933/52309_Cm_9161_NSS_SD_ Review_web_only.pdf, 10.04.2019.

House of Lords. European Union Committee, 6th Report of Session 2014-15. The EU and Russia: before and beyond the crisis in Ukraine, London, 20.02.2015, 
UK Parliament, https://publications.parliament.uk/pa/ld201415/ldselect/ldeucom/115/115.pdf, 10.04.2019.

Korsak E., Miernicka M., Zieliński M. (2017), Brytyjczycy i Rumuni w Orzyszu, 14.04.2017, „Polska Zbrojna”, http://polska-zbrojna.pl/home/articleshow/22359?t=Brytyjczycy-i-Rumuni-w-Orzyszu\#, 16.04.2019.

Koval N. (2018), United Kingdom, w: Understanding Strategic Adaptations: Security Strategies and Policies after 2014, red. H. Maksak, R. Q. Turcsányi, M. Vorotnyuk, Strategic Policy Institute, Bratislava-Kyiv.

Kramer A. E. (2018), Russia Expels 23 British Diplomats, Escaleting Row Over Ex-Spy's Poisoning, 17.03.2018, “The New York Times”, https://www.nytimes.com/2018/03/17/world/europe/russia-expel-britain-diplomats.html, 16.04.2019.

Lesiecki R. (2018), Batalion NATO w Polsce jest od roku. „Obietnica szczytu w Warszawie została zrealizowana”, 16.03.2018, Defence24, https://www. defence24.pl/batalion-nato-w-polsce-jest-od-roku-obietnica-szczytu-wwarszawie-zostala-zrealizowana, 16.04.2019.

Lorenz W. (2019), Priorytety obronne państw pólnocnej flanki NATO, 8.05.2019, Polski Instytut Spraw Międzynarodowych, https:/www.pism.pl/publikacje/ Priorytety_obronne_pa_stw_p_nocnej_flanki_NATO, 20.02.2020.

Memorandum on security assurances in connection with Ukraine's accession to the Treaty on the Non-Proliferation of Nuclear Weapons, 5.12.1994, United Nations, https://reaties.un.org/doc/Publication/UNTS/No\%20Volume/52241/ Part/I-52241-0800000280401fbb.pdf, 10.04.2019.

Ministry of Defence (2017), UK steps up to take command of NATO task force, 11.01.2017, Government UK, https://www.gov.uk/government/news/uk-steps-up-to-take-command-of-nato-task-force, 16.04.2019.

Morris N., Usborne D., Ukraine crisis: This is Europe's biggest crisis in the 21st century, warns William Hague as Russia defiantly threatens a military assault on Crimea, 4,03.2014, „The Independent”, https:/www.independent.co.uk/ news/world/europe/ukraine-crisis-western-countries-scramble-to-respond-torussia-as-acting-president-appeals-to-moscow-9166748.html, 16.04.2019.

NATO's Enhanced Forward Presence, 03.2019, NATO, https://www.nato.int/nato static_fl2014/assets/pdf/pdf_2019_04/20190402_1904-factsheet_efp_en.pdf, 16.04.2019.

Nicholls D. (2018), Gavin Williamson commits extra British troops in Ukraine to stop Russia ,reversing Cold War outcome’, 20.09.2018, „The Telegraph”, https:// www.telegraph.co.uk/news/2018/09/20/gavin-williamson-commits-extrabritish-troops-ukraine-stop-russia/, 16.04.2019.

Package of Measures for the Implementation of the Minsk Agreements, Minsk, 11.02.2015, United Nations, https://peacemaker.un.org/sites/peacemaker. un.org/files/UA_150212_MinskAgreement_en.pdf, 10.04.2019.

Press Association, British troops land in Estonia for Nato mission to deter Russia, 18.03.2017, „The Guardian”, https://www.theguardian.com/uk-news/2017/ 
mar/18/british-troops-land-in-estonia-for-nato-mission-to-deter-russia, 16.04.2019.

Protocol on the results of consultations of the Trilateral Contact Group, Minsk, 5.09.2014, OSCE, https://www.osce.org/home/123257, 10.04.2019.

RAF Typhoon Jets Arrive In Estonia, 25.04.2019, RAF, https:/www.raf.mod.uk/ news/articles/raf-typhoon-jets-arrive-in-estonia/, 16.04.2019.

Rowe P. (2016), Legal Accountability and Britain's Wars 2000-2015, Routledge, London-New York.

Szymański P. (2019), Konsekwencje brexitu dla polityki bezpieczeństwa Wielkiej Brytanii $i$ wschodniej flanki NATO, 3.04.2019, Ośrodek Studiów Wschodnich, https:/www.osw.waw.pl/pl/publikacje/komentarze-osw/2019-04-03/ konsekwencje-brexitu-dla-polityki-bezpieczenstwa-wielkiej, 28.02.2020.

Telegraph Reporters, British troops arrive in Estonia to deter Russian aggression in one of biggest deployments to region in decades, 18.03.2017, ,The Telegraph", https://www.telegraph.co.uk/news/2017/03/18/british-troops-arriveestonia-deter-russian-aggression-one-biggest/, 16.04.2019.

The Royal Welsh Arrive In Estonia, 30.10.2017, Forces Network, https://www.forces. net/news/royal-welsh-arrive-estonia, 16.04.2019.

Tomaszewski J. (2015), Wybrane aspekty polityki bezpieczeństwa Wielkiej Brytanii, „Bezpieczeństwo Narodowe”, nr IV.

Wales Summit Declaration Issued by the Heads of State and Government participating in the meeting of the North Atlantic Council in Wales, Newport, 5.09.2014, NATO, https://www.nato.int/cps/ic/natohq/official_texts_112964. htm, 10.04.2019.

Warsaw Summit Communiqué Issued by the Heads of State and Government participating in the meeting of the North Atlantic Council in Warsaw 8-9 July 2016, Warsaw, 9.07.2016, NATO, https://www.nato.int/cps/ic/natohq/official_texts_133169.htm, 10.04.2019.

Zieliński M. (2017), Jakim uzbrojeniem dysponuje Batalionowa Grupa Bojowa?, 25.04.2017, „Polska Zbrojna”, http://www.polska-zbrojna.pl/home/articleshow/22423?t=Jakim-uzbrojeniem-dysponuje-Batalionowa-Grupa-Bojowa-, 16.04.2019.

\section{The activities of the United Kingdom to strengthen the security of NATO's north-east flank in the face of Russia's military activity in Ukraine}

\section{Summary}

The subject of the article is the activities of the United Kingdom aimed at increasing the security of NATO's north-eastern flank countries in the context of the crisis in 
Ukraine. The first part of the text discusses the involvement of the United Kingdom in ensuring the security of Poland and the Baltic states in the 20th century, including, above all, retaining their independence. The second part is devoted to London's reaction to Russia's armed operations in Ukraine in the political and economic spheres. The third part discusses the military aspects of the United Kingdom's support for the security of Poland and the Baltic states during the crisis in Ukraine. The extent of London's political response to the crisis in Ukraine has been limited. Nevertheless, the United Kingdom has definitely joined the military activities to strengthen the security of NATO's north-eastern flank countries.

Key words: Great Britain, the crisis in Ukraine, the north-eastern flank of NATO, British-Russian relations 